\title{
THE ROLE OF CROWN ARCHITECTURE FOR LIGHT HARVESTING AND CARBON GAIN IN EXTREME LIGHT ENVIRONMENTS ASSESSED WITH A REALISTIC 3-D MODEL
}

\author{
by \\ FERNANDO VALLADARES ' \& ROBERT W. PEARCY ' \\ Centro de Ciencias Medioambientales, CSIC. Serrano, 115 dpdo. E-28006 Madrid (Spain) \\ - Section of Evolution and Ecology, University of California, Davis. CA 95616-8755 (USA)
}

\begin{abstract}
Resumen
VALLADARES, F. \& R.W. PEARCY (2000). El papel de la arquitectura vegetal en la captura de luz y la ganancia de carbono en ambientes lumínicos extremos evaluado mediante un modelo tridimensional realista. Anales Jard. Bot. Madrid 58(1): 3-16 (en inglés).

Se presentan los resultados principales de varios estudios sobre las adaptaciones del follaje a ambientes lumínicos extremos. Plantas de ambientes oscuros (sotobosques de bosques templados y tropicales) y de ambientes muy luminosos (ecosistemas abiertos de tipo Mediterráneo) han sido estudiadas mediante un modelo (YPLANT) que permite la reconstrucción tridimensional de la parte aérea de las plantas e identificar los rasgos estructurales que determinan la interceptación de luz y la fotosíntesis y transpiración potencial a nivel de toda la copa. Táxones no relacionados y con arquitecturas muy diferentes mostraron una eficiencia en la interceptación de luz similar (convergencia funcional). La comparación entre hábitat reveló grandes diferencias arquitecturales dependiendo de si la absorción de luz debía ser maximizada o mınimizada. Estas diferencias fueron observadas tanto entre especies de distintos hábitat como entre poblaciones de sol y de sombra de una misma especie debido al ajuste de la arquitectura del follaje al ambiente lumínico de cada individuo (plasticidad fenotípica). Los modelos tridimensionales realistas como YPLANT son herramientas indispensables en este tipo de estudios comparativos debido a la intrinseca complejidad de la arquitectura vegetal, y su desarrollo eficaz requiere de un intercambio fluido de ideas entre botánicos. ecólogos y creadores de modelos.
\end{abstract}

Palabras clave: Arquitectura del dosel, bosque tropical lluvioso, fotosíntesis. luz excesiva, modelo tridimensional, sombra, sotobosque, Heteromeles arbutfolia, Retama sphaerocarpa, Stipa tenacissima.

\footnotetext{
Abstract

Valladares, F. \& R.W. PEARCY (2000). The role of crown architecture for light harvesting and carbon gain in extreme light environments assessed with a structurally realistic 3-D model. Anales Jard. Bot. Madrid 58(1): 3-16.

Main results from different studies of crown architecture adaptation to extreme light environments are presented. Light capture and carbon gain by plants from low (forest understory) and high (open Mediterranean-type ecosystems) light environments were simulated with a 3-D model (YPLANT), which was developed specifically to analyse the structural features that determine light interception and photosynthesis at the whole plant level. Distantly related taxa with contrasting architectures exhibited similar efficiencies of light interception (functional convergence). Between habitats large differences in architecture existed depending on whether light capture must be maximised or whether excess photon flux density must be avoided. These differences are realised both at the species level and within a species because of plastic adjustments of crown architecture to the external light
} 
environment. Realistic, 3-D architectural models are indispensable tools in this kind of comparative studies due to the intrinsic complexity of plant architecture. Their efficient development requires a fluid exchange of ideas between botanists, ecologists and plant modellers.

Key words: 3-D model, crown architecture, excessive light, photosynthesis, shade, tropical rainforest. understory, Heteromeles arbutifolia, Retama sphaerocarpa, Stipa tenacissima.

\section{INTRODUCTION}

The shape of the crown and the arrangement of its foliage are the two most basic parameters affecting the light capture efficiency of plants (OKER-BLOM \& KELLOMÄKI, 1982; CHAZDON, 1985; DiCKMAN \& al., 1990; KUULUVAINEN, 1992). From a photosynthetic point of view, the most efficient canopy is achieved when all leaves are evenly illuminated at intermediate light flux densities (RUSSELL \& al., 1989). But this is achieved in nature only very rarely if at all (GIVNISH, 1988). In fact, light is frequently either limiting (e.g. forest understories) or excessive and potentially harmful in open environments when plant metabolism is impaired by environmental stresses (PEARCY, 1999). Crown architecture plays an important role in plant growth and survival because it affects both the allocation to leaf area and the way this leaf area is arranged and displayed (VALLADARES, 1999). In fact, the rather poor correlation between photosynthetic capacity and plant growth has been explained by the influence of architectural features such as leaf area ratio (POORTER \& REMKES, 1990; VAN DER WERF \& al., 1993). Most research has focused on the orientation and diurnal movements of individual leaves (EHLERINGER \& FORSETH, 1980; WERK \& EHLERINGEN, 1984; JURIK \& al., 1990) whereas little attention has been paid to the role of shoot and crown architecture in adjusting radiation interception to the capacity of the leaf to utilise it. Similarly, the packing of leaves around shoots and within the crown is important for avoiding photoinhibition or temperature stress (VALladares \& PEARCY, 1998). Defining an optimal crown design for a given environment is very difficult, because the crown of a plant has multiple functions and design constraints, and light capture is just one of them (see discussion in PeARCY \&
VALLADARES, 1999). However, the quantitative comparison and analysis of light capture by different plant species co-occurring in extreme light environments can provide significant ecological and evolutionary insights (NIKLAS, 1986, 1997; VALLADARES, 1999).

Here we present our results regarding two groups of studies of the adaptation of crown architecture to extreme light environments. In the first group we have studied architectural features of plants facing light limitations, and we have explored the influence of growth form and leaf arrangement on light interception in different plant species growing in the dark understory of a tropical rainforest. In the second case we have examined the photoprotective roie of plant architecture in Mediterranean-type ecosystems, where the solar radiation is very intense, especially during the summer, and can be harmful for plants in terms of causing high leaf temperatures or photoinhibition. An analysis of the influence of simple structural features such as petiole length or leaf angle on whole plant light capture and carbon gain is presented for each type of environment. Finally, the consequences for individual leaves of the light heterogeneity within a crown and the functional relevance of the structural plasticity allowed within a given plant architecture are addressed for the case of an evergreen chaparral shrub. All the studies presented here have relied heavily on a computer model (YPLANT), which was developed specifically to tease out the structural features that determine light interception and photosynthesis at the whole plant level (Pearcy \& Yang, 1996). Tree models have received increasing attention in recent years, which has led to an outstanding level of realism in simulating crown architecture in 3-D (e.g. Prusinkiewicz \& 
LINDENMAYER, 1996; SINOQUET \& al., 1997) and tree growth (e.g. PERTTUNEN \& al., 1996; Room \& al, 1996; Godin \& al., 1997). However, ecological and evolutionary studies of plant architecture have not benefited much from this technical development, which has focused mostly on visualisation and on agronomical and forestry applications. This situation is evidenced by the scarcity of ecological studies of the functional implications of plant form using functionalstructural plant models. The present brief account of ecological questions addressed with YPLANT is intended to bridge the gap between these two cultures and to stimulate a more fluid exchange of ideas between botanists, ecologists and plant modellers.

\section{YPLANT, A MODEL FOR SIMULATING CROWN GEOMETRY, LIGHT CAPTURE AND CARBON GAIN}

Light capture and potential carbon gain have been assessed using the 3-D model YPLANT (PEARCY \& YANG, 1996). YPLANT is a geometrically-based deterministic model that uses ray tracing techniques to calculate light interception, and it is well suited for simulating small to medium-size individual canopies (up to 1000 leaves). It can handle complex, irregularly branched architectures and provides output for both the whole crown and for individual leaves. The fluxes and light field geometry are based on standard equations for solar and sky radiation, and on the observed geometric distribution of canopy gap fraction as derived from canopy fisheye photographs. The model takes into account leaf absorbance and simulates assimilation from the absorbed photosynthetic photon flux density (PFD) for the sunlit and the shaded portions of the leaf separately using the non-rectangular hyperbolic model of light. YPLANT has been shown to accurately predict the measured frequency distribution Jf PFD on leaves both in the open and in the more complex light environment of the forest understory (Valladares \& PearCY, 1998). YPLANT does not take into account the photosynthetic response to temperature nor the reduction of photochemical efficiency by excessive irradiance (photoinhibition). However, these changes in the photosynthetic rates can be entered manually by modifying the settings and running the calculations for periods of daytime when conditions remain constant. For a more detailed description of YPLANT see (PEARCY \& YANG, 1996).

\section{SURVIVING IN THE DARKNESS OF THE FOREST UNDERSTORY}

Maximising light capture could be expected to have a high priority in terms of selective pressures under the limiting light conditions of shaded forest understories (PEARCY, 1983). Many analyses of plant shape have pointed out a general tendency to avoid leaf overlap and hence self-shading in understory plants (CHAZDON, 1984). Plagiotropic branching and distichous phyllotaxes have been shown as common solutions to the problem of selfshading (GIvNISH, 1986b). However, plagiotropic branches create greater static loads than orthotropic branches, and many plants have developed other architectural solutions, which are biomechanically more efficient (MATTHECK, 1991). Even though there is extensive evidence of a remarkable physiological acclimation to shade of a wide variety of plant species (EVANS \& al., 1988; GIVNISH, 1988; OSMOND \& CHOw, 1988), there is also evidence that growth in the shade can be more sensitive to architectural traits such as leaf area and efficiency of leaf display than to leaf-level photosynthesis (ACKERLY \& BAZZAZ, 1995). Simple structural features such as petiole length can have a great impact on light capture efficiency (PEARCY \& YANG, 1998). And different architectures may provide similar efficiencies under the strong selection for maximising light capture that takes place in shaded environments (CHAZDON, 1991). These two aspects will be illustrated with the case of Adenocaulon bicolor in the understory of a Californian redwood forest, and with the case of 20 plant species co-occurring in the understory of a lowland, tropical rainforest in Panama. 


\section{The relevance of simple structural features}

Many understory plants exhibit a simple architecture due to the minimisation of supporting or connecting structures (stems, branches) and the maximisation of light capture structures (leaves) (CHAZDON, 1986). Simple architectures are ideal for the exploration of the functional implication of specific parameters affecting the arrangement of leaves in the 3-D space since their simplicity makes them suitable for optimality analysis (GIVNISH, 1986a; PARKER \& SMITH, 1990). This is the case for the crown of the redwood forest understory herb Adenocaulon bicolor, which has a rosette growth form with deltoid leaves borne on the end of long petioles (Fig. 1). This simple architecture minimised mutual shading of leaves and gave very high efficiencies of light absorption (PEARCY \& YANG, 1998). Light absorption (as simulated with YPLANT) was significantly affected by petiole length. In fact, the optimum petiole lengths were equal to the observed lengths. When petiole length was manipulated in the computer simulations so the biomass partitioning between leaf blade and petiole was varied but the total aboveground biomass was kept constant, the actual partitioning found for real plants exhibited the highest values of diffuse PFD absorbed per day and per plant (Fig. 1). As petioles were shortened, and hence their mass decreased. leaf area increased but so did mutual shading among leaves. Lengthening the petioles avoided self-shading almost completely but resulted in less lamina area. Another rather simple architectural feature of A. bicolor, the divergence angle between successive leaves in the phyllotactic spiral, also conformed to an optimal behaviour, since any departure from the Fibonacci fraction decreased light absorption efficiency at the whole plant level (PEARCY \& YANG, 1998).

\section{Different architectural solutions \\ to the same constraint}

Despite the extremely low levels of irradiance experienced in the understory of tropical rainforests, a relatively high diversity of shrubs. herbs, and seedlings of tree species can be found co-occurring within small areas (TERBORGH, 1992) . These plants suffer shading not only from the forest canopy and neighbouring plants, but also from the leaves of their own crowns. Architectures that minimise this self-shading should be at an advantage. In order to investigate the diversity of solutions to this problem, the efficiency of light capture was compared in 20 species from a tropical rainforest understory on Barro Colorado Island, Panama (Fig. 2). The species studied included understory palms. saplings of canopy trees, shrubs, and a wide variety of monocotyledons of contrasting architectures (see list of species in the legend of Fig. 2). Plant size, total leaf area, mean leaf size and phyllotaxy varied remarkably among the species considered. The species significantly differed in the fraction of above ground biomass invested in support, a structural parameter that had a large coefficient of variation (Fig. 2). This parameter represents the costs in terms of biomass of achieving a given foliage display in the 3-D space. The most remarkable result of this comparison was not the architectural divergence but rather the functional convergence of the architectures of different plant species surviving in this very low light environment. Light absorption efficiencies (calculated by YPLANT as a fraction of the total light absorbed throughout the day by a horizontal surface with no self shading and placed in the same light environment of the plant) were high and rather similar among the species, as indicated by a coefficient of variation 3 times lower than that for the above ground biomass (Fig. 2). Despite the divergences in phyllotaxy, investments in support, leaf size, etc, the mutual shading of the leaves during the brightest hours of the day was low and generally around $10 \%$ of the foliage area in all species examined. Thus, the rare spiromonostichous phyllotaxis of the monocot herb Costus pulverulentus Presl, Rel. Haenk., apparently a unique solution to avoid selfshading, was no better for this purpose than the spiral phyllotaxis of the saplings of the canopy tree Thevetia ahouai (L.) A. DC. or 


\section{Early morning view}
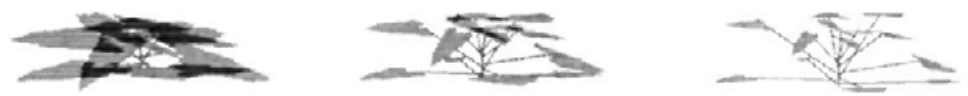

\section{Midday view}

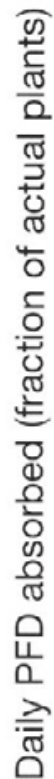
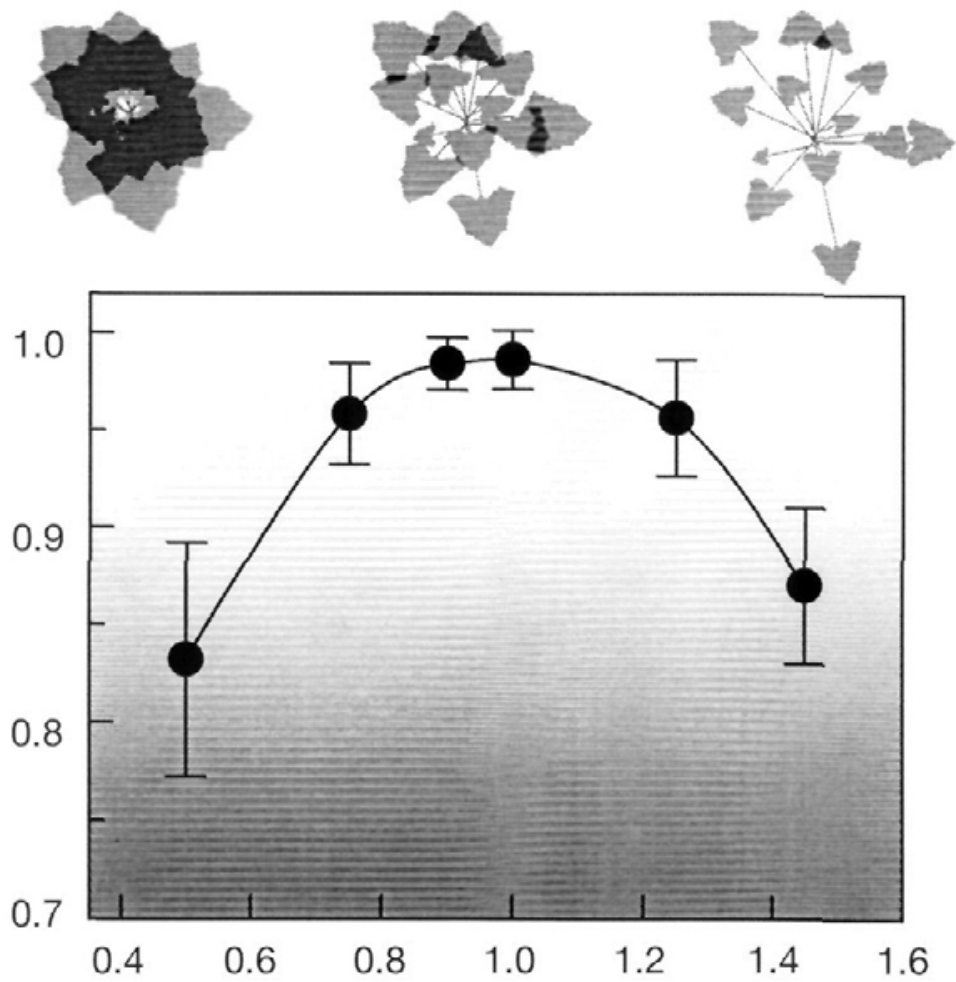

Petiole length (fraction of actual length)

Fig. 1.-Simulated diffuse PFD absorbed per day by Adenocaulon bicolor Hook in a redwood forest understory (California, USA) as a function of petiole length. Petiole length was varied from 0.4 to 1.4 the real length observed on the plants in the field, and leaf size was varied accordingly to keep the above ground mass of the plant constant. Early morning and midday views (as seen from the sunpath) of one of the simulated plants with 3 different petiole lengths $(0.4$, $1,1.4$ times real lengths) are shown above the graph. Note the decreasing leaf overlap with increasing petiole length. Each value is the mean \pm SD of five plants. [Elaborated from PEARCY \& YANG (1998).] 


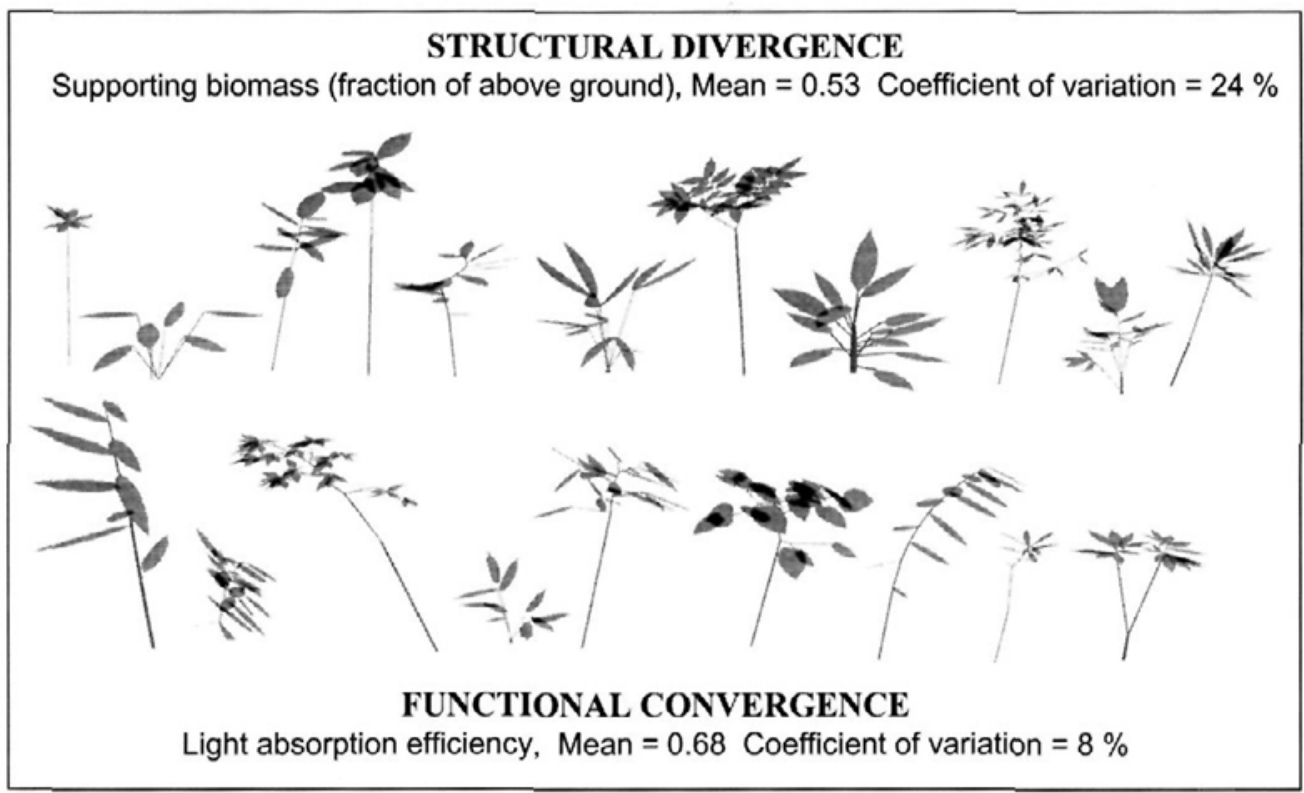

Fig. 2.-Architectural diversity in the darkness of a forest understory. Results from a comparison of 20 plants species of contrasting architectures and growth forms co-occurring in the understory of a lowland, tropical rainforest in Panama. The species significantly differed in the fraction of above ground biomass invested in support, while converged in the light absorption efficiency (calculated by YPLANT as a fraction of the total light absorbed throughout the day by a horizontal surface with no self shading and placed in the same light environment of the plant). This fact was indicated by the different coefficient of variation of each parameter. Climbers and lianas have been omitted. Three different individuals of each species were measured and the mean was taken for each species. The species are from upper left to bottom right Alseis blackiana Hemsl., Calathea inocephala (Kuntze) Kenn. \& Nicolson, Calophyllum longifolium Willd., Coccoloba manzanillensis Beurl., Costus pulverulentus Presl, Cyclanthus bipartitus Poit., Dichorisandra hexandra (Aubl.) Standl. in Standl. \& Calderón, Dieffenbachia longispatha Engl. \& K. Krause, Faramea occidentalis (L.) A. Rich., Geonoma interrupta (Ruiz \& Pav.) Mart., Gustavia superba (Humb., Bonpl. \& Kunth) Berg., Heliconia vaginalis Benth., Hybanthus prunifolius (Schult.) Schulze-Menz, Ossaea quinquenervia (P. Mill.) Cogn. in A. DC., Pharus latifolius L., Piper cordulatum C. DC., Piper reticulatum L., Renealmia cernua (Sw.) J.F. Macbr., Thevetia ahouai (L.) A. DC., Xanthosoma helleborifolium (Jacq.) Schott.

the pseudodistichous foliage of the shrub Hybanthus prunifolius (Schult.) Schulze (Valladares, Skillman and Pearcy, in preparation). These results show that the complex interactions between the different geometrical properties of a crown can lead to the situation found here that quite different character combinations can result in functionally equivalent architectures. The many functions carried out and design constraints imposed on the crowns may have led to this wide variety of contrasting, cooccurring architectures, with functional convergence on what seems to be the most crucial constraint in a dark understory: light capture.

\section{DEALING WITH HIGH IRRADIANCE IN ARID ENVIRONMENTS}

Plants in open environments are exposed to high irradiance and exhibit two general strategies, one physiological (CoRNIC, 1994; LONG \& al., 1994) and the other one structural or architectural (avoidance of excessive irradiance by structural features that reduce the leaf area directly exposed to the sun). Plants exposed to high irradiance stress usually combine these two strategies. Even though some physiological photoprotective mechanisms, such as energy dissipation via the xanthophyll cycle, have been shown to be both efficient and widespread among wild 
plants (DEMMIG-ADAMS \& AdAMS, 1992; RUBAN \& HORTON, 1995), structural avoidance of excessive irradiance can be crucial for survival in high light environments (VALLADARES \& PEARCY, 1997). Photoprotection via xanthophyll cycle has been shown to interact significantly with architectural features such as leaf angle and orientation (ADAMS \& al., 1992; LOVELOCK \& ClOUGH, 1992).

\section{The effect of leaf angle}

Leaf angle strongly influences the interception or radiation by individual leaves and has been well documented as a highly plastic character (MCMILLEN \& MCCLENDON, 1979; WALLACE \& DUNN, 1980; HIKOSAKA \& al., 1994). We studied the role of leaf angle in the chaparral shrub Heteromeles arbutifolia M. Roem. for achieving an efficient compromise between maximising carbon gain while minimising the time that the leaf surfaces were exposed to PFDs that exceeded requirements for saturating photosynthesis and therefore were potentially photoinhibitory (VAlladares \& PEARCY, 1998). When $H$. arbutifolia grows in the open chaparral environment it has very steep foliage (mean $71.3^{\circ}$; VALLADARES \& PEARCY, 1998). We have studied the effect of leaf angle in this species both by changing the leaf angle in the computer files used to specify the architecture in YPLANT (Fig. 3), and with plants in the field under their natural light regimes by reorienting leaves from their normally steep angles to a horizontal position with wire restraints. Patterns of light interception simulated with YPLANT agreed very well with data obtained by mounting light sensors on real leaves in the field. Light interception during a clear summer day by shoots simulated with horizontal leaves was up to $40 \%$ greater than those simulated with natural leaf angles. However, the potential carbon gain was only $10 \%$ higher for the shoots with horizontal leaves than for the real shoots due to the non-linear photosynthetic response to light (no temperature or photoinhibitory effects were considered). The time that the leaf was exposed to super-saturating PFD's and to the consequently increased leaf temperatures was dramatically increased in shoots simulated with horizontal leaves (Fig. 3). And when leaves were restrained to horizontal in water stressed plants with low stomatal conductances, leaf temperature rose to values that exceeded the critical temperature for the stability of PSII (VALLADARES \& PEARCY, 1997), and also ultimately led to leaf necrosis (Fig. 3).

\section{Different strategies to cope with high light in arid environments}

Steeply oriented foliage and a moderate to high level of self-shading reducing the photosynthetic surface area displayed during the central hours of the day are characteristic structural features of the crowns of many plants from high light environments ( $\mathrm{V}_{\mathrm{A}}$ LLADARES \& PearCy, 1998, 1999; VallaDARES \& PugnaIRE, 1999). But despite this functional similarity, species from these environments differ significantly in their growth form, above ground architecture and rate of leaf turnover (SPECHT, 1969; RAVEN, 1973; Di CASTRI \& al., 1981; JofFRE \& al., 1999). We have compared light interception in five evergreen species growing in Mediterranean-type ecosystems in California and Spain. Two different strategies were observed in the way these plants dealt with high irradiance stress: one group of species exhibited the structural features mentioned above, which translated into a permanent reduction of light absorption efficiency, while the other group exhibited a higher light absorption efficiency coupled with a flexible capacity to shed up to $50 \%$ of their foliage during the summer drought (droughtdeciduous shrubs; Fig. 4). The fraction of leaf area that was displayed during mid day of a typical spring day was only $20-30 \%$ of the total leaf area of the shoot in the first group of species, while it was $50 \%$ in the second group (Fig. 4). Evergreen sclerophyllous shrubs generally have lower photosynthetic capacities than malacophyllous, droughtdeciduous shrubs, since they can amortise their costs of production over a longer period of time (MOONEY \& DUNN, 1970; WERNER \& al., 1999). Photoinhibition can reduce carbon 


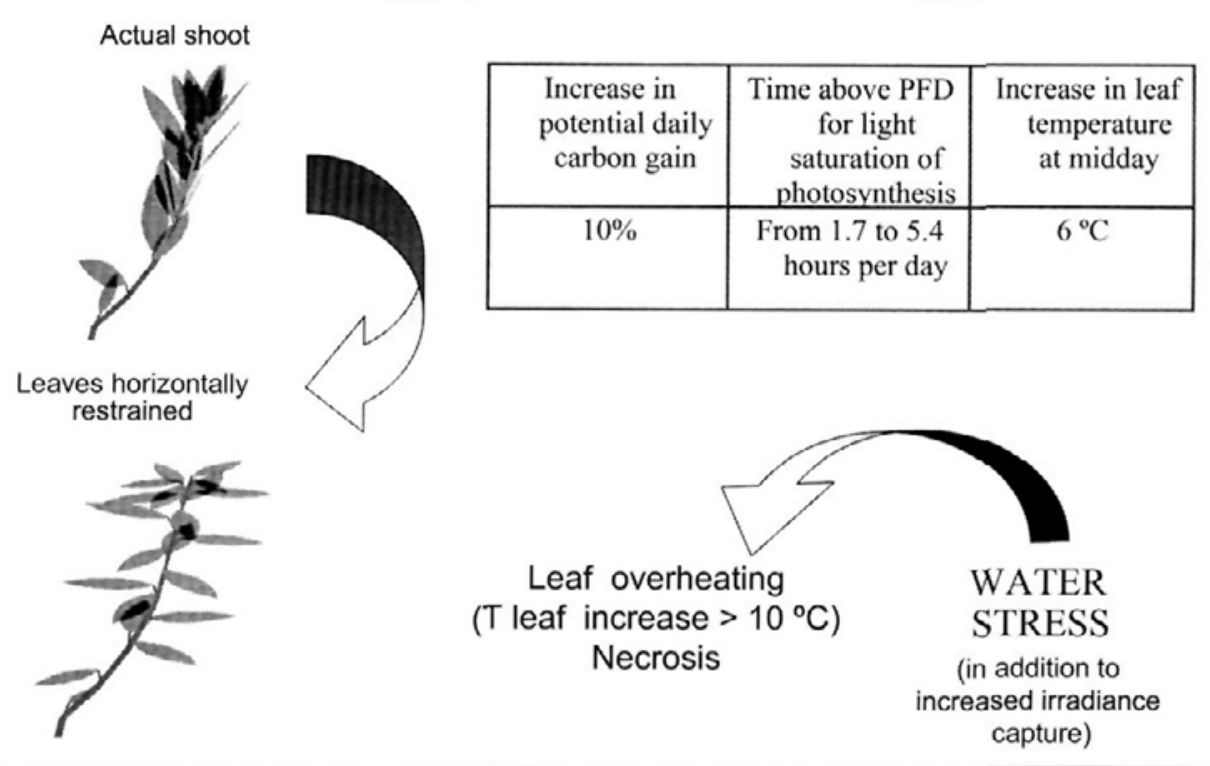

Fig. 3.-Influence of leaf angle on potential carbon gain (simulated with YPLANT), time above PFD for light saturation of photosynthesis, and leaf temperature in shoots of the chaparral shrub Heteromeles arbutifolia M. Roem. Results are shown for changes from shoots with normal, steep leaf angles to shoots with leaves restrained horizontally. Interaction with water stress increases leaf temperature. All values are mean of five different plants. [Elaborated from VALLADARES \& PEARCY (1998), with leaf temperature data obtained from real plants in the field (VALlADARES \& PEARCY, 1997).]

gain, so evergreen species with low photosynthetic capacities should be better photoprotected than drought-deciduous species, which can partition more of the absorbed PFD into carbon fixation. The observed tendency of higher structural photoprotection in evergreen than in drought-deciduous species is consistent with the former sacrificing instantaneous carbon gain while maintaining the capability for continued long term productivity (VALladares \& PEARCY, 1997) required to ensure recovery of their relatively high costs of leaf production (MERINO \& al., 1982; MERINO, 1987). Mediterranean species that compensate for a short leaf life span by a high carbon assimilation in order to coexist or outcompete evergreen species must harvest plenty of light to take full advantage of their photosynthetic machinery. But with the characteristic water deficit of Mediterranean environments, enhanced light capture on a leaf area basis is a risky strategy in these habitats (risks of photoinhibition and leaf overheating). Thus these plants must also possess a significant structural and functional plasticity to cope with environmental changes.

The costs in terms of missed opportunity for carbon gain (comparing plant crowns with equivalent horizontal photosynthetic surfaces) due to the permanent architectural features that reduced leaf display were studied in the ussock grass Stipa tenacissima L. and in the leguminous, leafless shrub Retama sphaerocarpa (L.) Boiss. (Valladares \& Pugnaire, 1999). Similar conclusions were obtained in other studies with tussock grasses (RYEL \& al., 1993, 1994; RYEL \& BEYSCHLAG, 1995). The costs in terms of lost carbon gain emanating from the architectures for the two species studied by Valladares \& Pugnaire were similar to those imposed by the summer drought (around $50 \%$ of the potential carbon gain), the main limiting factor for plant survival in their natural semiarid location in the south of Spain. This elevated cost of structural photoprotection emphasised the ecological relevance of avoidance of high irradiance stress in open and arid environments. 


\section{COMPLEX CROWNS, INTERNAL LIGHT GRADIENTS AND THE CONSEQUENCES FOR INDIVIDUAL LEAVES}

A consequence of the increase in plant size is almost invariably an increase in self-shading. Thus, while leaves on small seedlings may experience similar light environments, large and complex crowns exhibit a remarkable heterogeneity of light environments created by the crowns themselves, which in turn influences the rates of whole plant photosynthesis, leaf ageing and acclimation (HIKOSAKA \& al., 1993, 1994; Kull \& al., 1995; KULl \& JARVIS, 1995). Interactions between light microenvironment, nitrogen allocation and photosynthetic characteristics generate a remark-

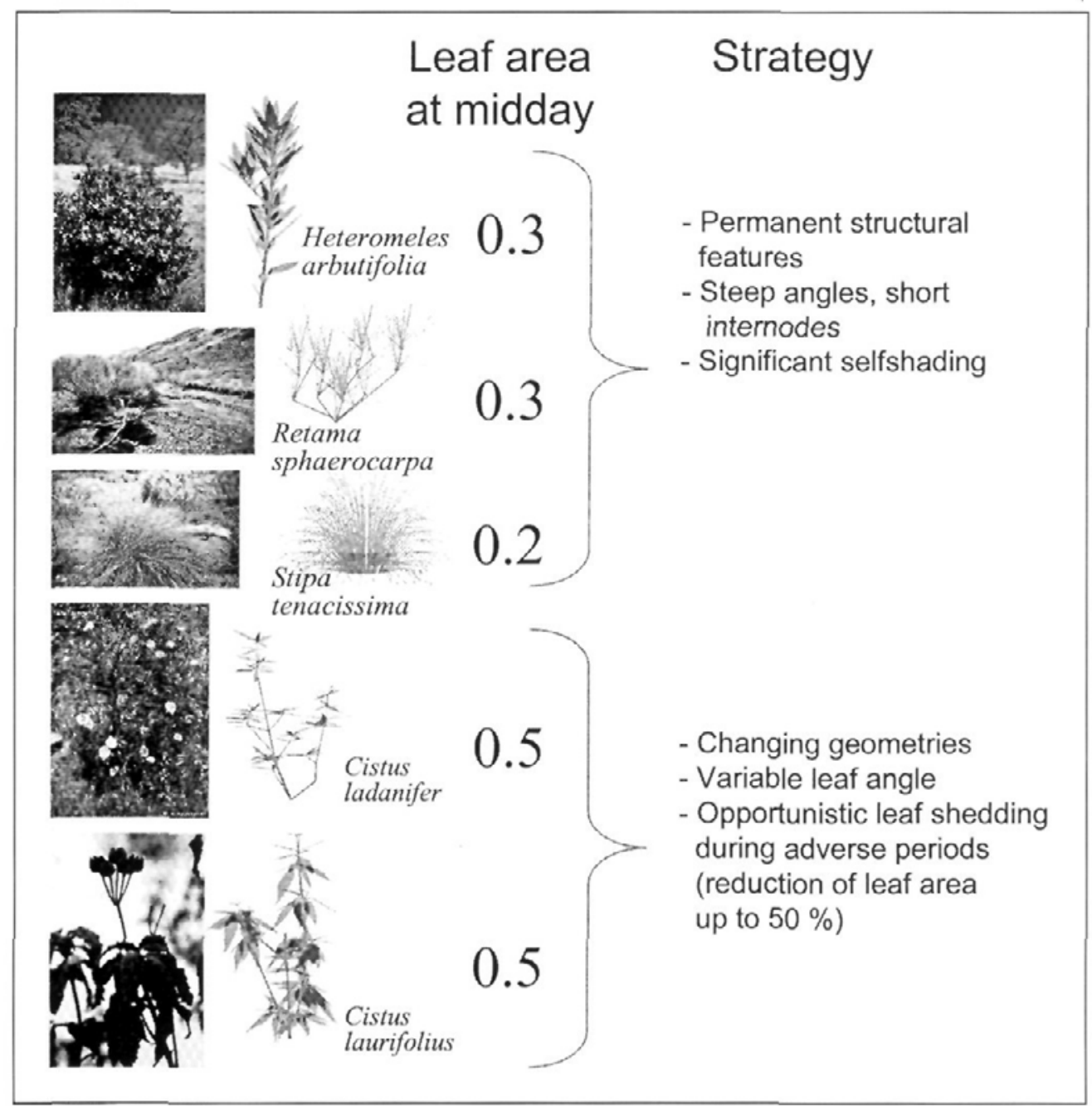

Fig. 4.-Fraction of total leaf area displayed (directly exposed to the sun) at midday and strategy for irradiance avoidance in five species from high light environments in Mediterranean-type ecosystems. The species are form top to bottom Heteromeles arbutifolia M. Roem. (evergreen shrub), Retama sphaerocarpa L. (Boiss.) (leguminous leafless shrub), Stipa tenacissima L. (tussock grass), Cistus ladanifer L. (semideciduous shrub), Cistus laurifolius L. (semideciduous shrub). 
able functional heterogeneity within the foliage of a complex crown, which must be known in order to understand and predict plant productivity (LE RouX \& al., 1998). The continuous growth of the apical meristems of the shoots of a shrub like Heteromeles arbutifolia generates two opposing gradients, one of increasing PFD in the basal to apical direction and another one of increasing leaf age in the opposite direction (Fig. 5). Even though the apical position with its high PFD would seem to be optimal for photosynthesis these leaves are likely to experience photoinhibition and overheating. Thus, somewhat lower leaves that benefit from some shading may contribute the most to the whole shoot carbon gain in sclerophyll shrubs like $H$. arbutifolia (VALLADARES \& Pearcy, 1999). The extent of shade acclimation of lower leaves of the shoot can vary significantly from one species to another. Moreover, it is difficult in canopies to separate ageing effects from shade acclimation (HIKOSAKA \& al., 1993; HIKOSAKA \& al., 1994). For example, lower leaves of $H$. arbutifolia exhibited lower photosynthetic capacities but no change in light compensation points. Moreover, there was no evidence that these changes significantly enhanced carbon gain as compared to simulations where the photosynthetic characteristics were maintained constant for all leaves on the shoot. However, shade acclimation of lower leaves in the Mediterranean sclerophyll tree Quercus coccifera $\mathrm{L}$. significantly enhanced carbon gain by the whole plant as compared to the condition where all leaves had the same photosynthetic characteristics (CALDWELL \& al., 1986). This difference is likely due to the greater self-shading in $Q$. coccifera as compared to $H$. arbutifolia crowns. The role of sun-shade acclimation of individual leaves for whole tree performance has also been explored in the black alder [Alnus glutinosa

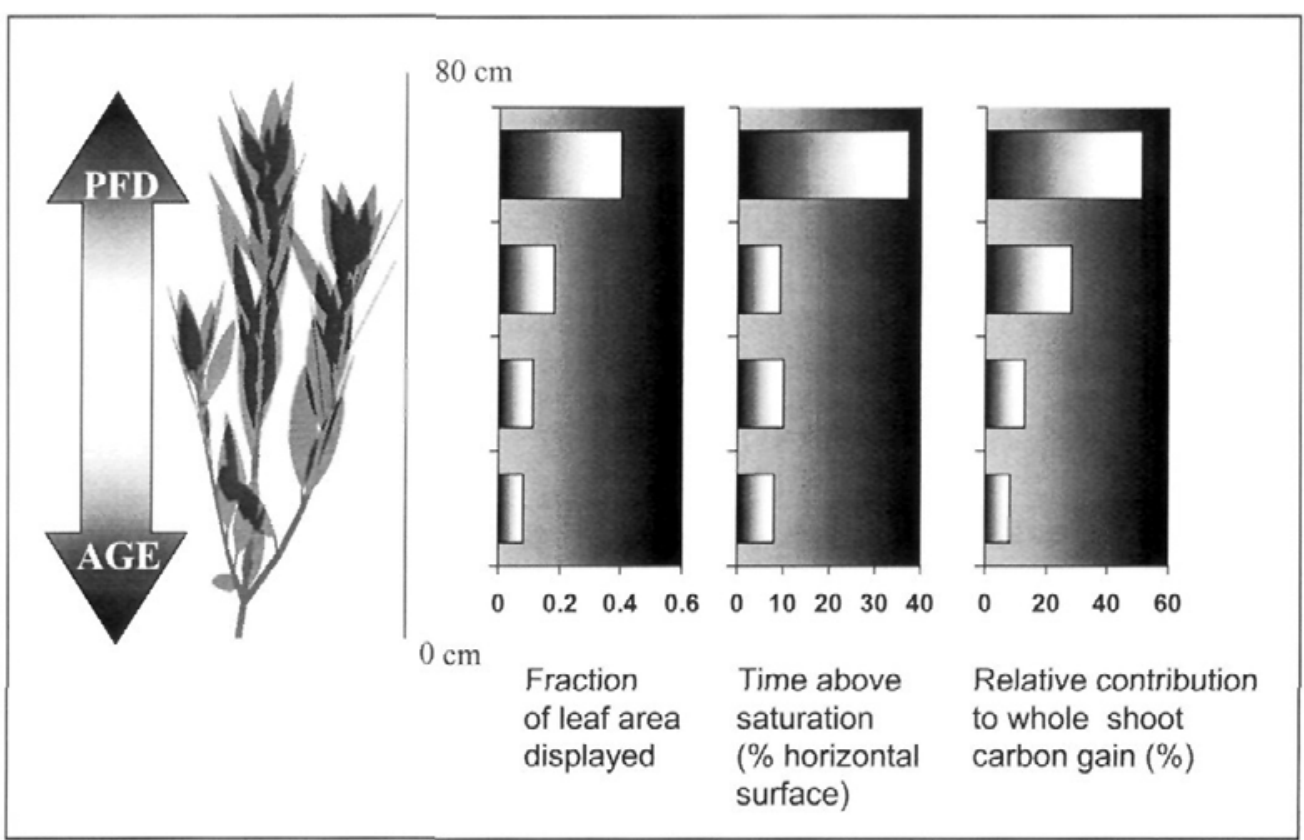

Fig. 5.-Influence of the leaf position along the vertical axis of a shoot of Heteromeles arbutifolia on the fraction of leaf area displayed at midday, on the time absorbing PFD saturating for photosynthesis (expressed as percent of that of a horizontal surface with the same photosynthetic response to light), and on the relative contribution of a given leaf to whole shoot potential carbon gain. The vertical axis combines the opposing PFD and age gradients. Each value is the mean of 50 leaves ( 10 from each of 5 different shoots). 
(L.) Gaertn.] by means of the object-oriented model ALMIS (ESCHENBACH, 1996, 1998). This model has been specifically designed to compare the competitive advantage of black alder trees with leaves of different capacities to acclimate to shade. The issue of the relative contribution of individual leaves to whole plant productivity, or in other words, the assessment of the value of a leaf (HARPER, 1989 ), is a fitting scenario for the application of structural-functional models. Single-leaf physiology must be, however, accurately parameterised.

\section{FUNCTIONAL PERSPECTIVE OF ARCHITECTURAL PLASTICITY}

Despite the genetic determination of the architectural plan of a given species, plants exhibit a remarkable phenotypic plasticity, that is, a remarkable capacity of their genotypes to produce different adaptive phenotypes under different environments (Schlichting, 1986; Schlichting \& PIGLIUCCI, 1998; VAlLADARES \& al., 2000b). Changing and heterogeneous environments seem to lead to evolution of increased plasticity, whereas stable or unpredictable environments seem to lead to specialisation and phenotypic stability (VALLADARES, 1999; VALLADARES \& al., 2000a, b). Light is both spatially and temporally heterogeneous. Thus, both the dynamics of canopy development and leaf demography, and the resulting spatial patterns of leaf display must be considered (Pearcy \& Valladares, 1999). Most of the studies dealing with plant acclimation to different light environments were focused principally on leaf photosynthetic responses (BOARDMAN, 1977; EVANS \& al., 1988; OSMOND \& CHOW, 1988), while structural changes influenced by light and their functional implications for plant performance have received significantly less attention (Givnish, 1988; Valladares \& PEARCY, 1998). Plant structure seems to be less plastic than physiology (VALlaDARES, 1999; VAlladares \& al., 2000b), but sizeable architectural plasticity has been observed within a given species and often corresponds with important functional changes of the crown (VALLADARES, 1999). The functional implications of architectural plasticity have been explored in $H$. arbutifolia by in situ comparisons of sun and shade populations. Despite having 7 times more PFD available, sun shoots absorbed only 3 times more PFD and had potential daily carbon gains less than double of those of shade shoots of plants growing in the understory of an evergreen oak woodland (Table 1; Valladares \& Pearcy, 1998).

\section{TABLE 1}

DIFFERENCES IN THE AVAILABLE PFD, ABSORBED PFD, AND POTENTIAL CARBON GAIN BETWEEN SUN AND SHADE SHOOTS OF HETEROMELES ARBUTIFOLIA M. ROEM. FROM NATURAL POPULATIONS IN A CALIFORNIAN CHAPARRAL-WOODLAND FORMATION

[Data are the mean of five different plants. Elaborated from VALLADARES \& PEARCY (1998)]

\begin{tabular}{|c|c|c|c|c|}
\hline & Sun shoots & Shade shoots & Sun/shade ratio & $\begin{array}{c}\text { Cause of } \\
\text { reduction in } \\
\text { Sun/shade ratio }\end{array}$ \\
\hline $\begin{array}{l}\text { Available PFD } \\
\left(\mathrm{mol} \mathrm{m}^{-2} \text { day }^{-1}\right)\end{array}$ & 54.3 & 7.7 & & \\
\hline $\begin{array}{l}\text { Absorbed PFD } \\
\left(\text { mol m}^{-2} \text { day-1) }\right.\end{array}$ & 14.5 & 4.3 & & $\begin{array}{r}\text { Crown } \\
\text { architecture }\end{array}$ \\
\hline $\begin{array}{l}\text { Potential carbon gain } \\
\left(\mathrm{mmol} \mathrm{CO}_{2} \mathrm{~kg}^{-1} \text { day-1) }\right.\end{array}$ & 76.2 & 52.6 & 1.4 & $\begin{array}{l}\text { Physiology of } \\
\text { photosynthesis }\end{array}$ \\
\hline
\end{tabular}


Plasticity in photosynthetic properties, both at the single leaf and whole plant levels, lead to a greater homeostasis in growth and resource use efficiency (PEARCY \& Valladares, 1999). Architectural plasticity influences leaf display and light capture allowing plants to effectively exploit a wide range of light environments.

\section{CONCLUSION}

The study cases presented here are remarkable examples of functional convergence under extreme light conditions, with different distantly related taxa with contrasting architectures having similar efficiencies of light interception. Among habitats large differences in architecture exist depending on whether light capture must be maximised (shaded understories) or whether excess PFD must be avoided. These differences are realised both at the species level and within a species because of plastic adjustments of crown architecture to the external light environment. Due to the intrinsic complexity of plant architecture, realistic, 3-D architectural models incorporating leaf physiological responses are indispensable tools in comparative studies of crown geometry, light capture and wholeshoot physiological performance.

\section{ACKNOWLEDGEMENTS}

Thanks are due to Lucía Ramírez, Eloísa Lasso, and Rob Wolf for help in the collection of field data, and to Javier Navarro, Francisco Pugnaire, Luis Balaguer, Esteban Manrique and John Skillman for collaborative work and fruitful discussions. Financial support was provided by Spanish CICYT (grant AMB98-1 108-C04-01).

\section{REFERENCES}

ACKERLY, D.D. \& F.A. BAZZAZ (1995). Leaf dynamics, self-shading and carbon gain in seedlings of a tropical pioneer tree. Oecologia 101: 289-198.

ADAMS, W.W. M. VOLK. A. HOEHN \& B. DEMMIG-ADAMS (1992). Leaf orientation and the response of the xanthophyll cycle to incident light. Oecologia 90 : 404-410.
BoARDMAN, N.K. (1977). Comparative photosynthesis of sun and shade plants. Annual Rev. Pl. Phwsiol. 28: 355-377.

Caldwell, M.M., H.P. Meister, J.D. Tehunen \& O.L. LANGE (1986). Canopy structure, light microclimate and leaf gas exchange of Quercus coccifera L. in a Portugese macchia: measurements in different canopy layers and simulations with a canopy model. Trees 1: 25-41.

Chazdon, R. (1986). The costs of leaf support in understory palms. Economy versus safety. Amer. Naturalist 127: 9-30.

CHAZDON, R.L. (1984). Ecophvsiology and architecture of three rain forest understony palm species. Ph.D. Thesis, Cornell University. Ithaca, New York.

Chazdon, R.L. (1985). Leaf display, canopy structure and light interception of two understory palm species. Amer. J. Bot. 72: 1493-1502.

Chazdon, R.L. (1991). Plant size and form in the understory palm genus Geonoma - are species variations on a theme? Amer. J. Bot. 78: 680-694.

CORNIC, G. (1994) Drought stress and high light effects on leaf photosynthesis. In: N.R. Baker \& J.R. Bowyer (eds.). Photoinhibition of photosvnthesis. From molecular mechanisms to the field: 297-314. Oxford.

DEMMIG-AdAMS, B. \& W.W. AdAms (1992). Photoprotection and other responses of plants to high light stress. Annual Rev. Pl. Physiol. Pl. Molec. Biol. 43: 599-626.

Di CASTRI, F, D.W. GOOdALl \& R.L. SPECHT (1981). Mediterranean-type shrublands. Ecosystems of the World. Amsterdam.

DickmanN, D.I., D.A. MichaEl, J.G. Isebrands \& S. WESTIN (1990). Effects of leaf display on light interception and apparent photosynthesis in two contrasting Populus cultivars during their second growing season. Tree Physiol. 7: 7-20.

EHLERINGER, J. \& I. FORSETH (1980). Solar tracking by plants. Science 210: 1094-1098.

EsCHENBACH, C. (1996). Zur Ökophysiologie der Primärproduktion der Schwarzerle [Alnus glutinosa (L.) Gaertn.]. Verh. Ges. Ökol. 33: 89-95.

ESCHENBACH, C. (1998). Modelling growth, development and architecture of black alder trees with an object oriented approach. ASU Newsletter 24: 75-86.

Evans, J.R., S. von CaEmmerer \& W.W. ADAMS III (1988). Ecology of photosynthesis in sun and shade. Melbourne.

GivisisH, T.J. (1986a) Introduction to: On the economy of plant form and function. In: T.J. Givnish (ed.). On the economy of plant form and function: 1-19. New York.

Givnish. T.J. (1986b). On the economy of plant form and function. New York.

GryNiSH. T.J. (1988). Adaptation to sun and shade: a whole-plant perspective. Austral. J. Pl. Physiol. 15: 63-92.

Godin, C., Y. Guedon, E. Costes \& Y. Caraglio (1997). Measuring and analysing plants with the AMAPmod software. In: M.T. Michalewicz (ed.), Plants to Ecosystems. Adrances in computational life sciences: 53-81. Collngwood. Australia. 
HARPER, J.L. (1989). The value of a leaf. Oecologia 80: 53-58.

Hikosaka, K., K. OKada, I. Terashima \& S. Katoh (1993). Acclimation and senescence of leaves: their roles in canopy photosynthesis. In: H.Y. Yamamoto \& C.M. Smith (eds.), Photosynthetic responses to the environment: 1-13. New York.

Hikosaka, K., I. Terashima \& S. Katoh (1994). Effects of leaf age, nitrogen nutrition and photon flux density on the distribution of nitrogen among leaves of a vine (Ipomoea tricolor Cav.) grown horizontally to avoid mutual shading of leaves. Oecologia 97: 451-457.

JoFFRE, R., S. RAMBAL. \& C. DAmesin (1999). Functional attributes in Mediterranean-type ecosystems. In: F.I. Pugnaire \& F. Valladares (eds.), Handbook of functional plant ecology: 347-380. New York.

Jurik, T.W. H.Z. Zhang \& J.M. Pleasants (1990). Ecophysiological consequences of non-random leaf orientation in the prairie compass plant, Silphium laciniatum. Oecologia 82: 180-186.

Kull, O., A. Aan \& T. Soelsepp (1995). Light interception, nitrogen and leaf mass distribution in a multilayer plant community. Funct. Ecol. 9: 589-595.

KuLL, O. \& P.G. JARVIS (1995). The role of nitrogen in a simple scheme to scale up photosynthesis from leaf to canopy. Pl. Cell Environm. 18: 1174-1182.

KuUluvainen, T. (1992). Tree architectures adpated to efficient light utilization: is there a basis for latitudinal gradients? Oikos 65: 275-284.

Le Roux, X., H. Sinoquet \& M. Vandame (1998). Spatial distribution of leaf dry weight per area and leaf nitrogen content in relation to local radiation regime within an isolated tree crown. Tree Physiol. (in press).

LoNG, S.P., S. Humphries \& P.G. Falkowski (1994). Photoinhibition of photosynthesis in nature. Annual Rev. Pl. Physiol. Pl. Molec. Biol. 45: 633-662.

LOVELOCK, C.E. \& B.F. ClOuGH (1992). Influence of solar radiation and leaf angle on leaf xanthophyll concentrations in mangroves. Oecologia 91 : 518-525.

MATTHECK, G.C. (1991). Trees. The mechanical design. New York.

MCMillen, G.G. \& J.H. MCClendon (1979). Leaf angle: an adaptive feature of sun and shade leaves. Bot. Gaz. 140: 437-442.

MERINO, J. (1987) The costs of growing and maintaining leaves of mediterranean plants. In: J.D. Tenhunen, F.M. Catarino, O.L. Lange \& W.C. Oechel (eds.), Plant response to stress (NATO ASI Series Vol. G15): 553-564. Berlin, Heidelberg.

Merino, J., C. Field \& H.A. MoOney (1982). Construction and maintenance costs of mediterranean-climate evergreen and deciduous leaves. I. Growth and $\mathrm{CO}_{2}$ exchange analysis. Oecologia 53: 208-213.

MoOney, H.A. \& E.L. DunN (1970). Photosynthetic systems of Mediterranean-climate shrubs and trees of California and Chile. Amer. Naturalist 104: 447-453.

NiKLAS, K.J. (1986). Evolution of plant shape: design constraints. Trends Ecol. Evol. 1: 67-72.

NIKLAS, K.J. (1997). The evolutionary biology of plants. Chicago.

OKER-Blom, P. \& S. KellomÁK (1982). Theoretical computations on the role of crown shape in the absorption of light by forest trees. Math. Biosci. 59: 291-311.

OSmOND, C.B. \& W.S. Chow (1988). Ecology of photosynthesis in the sun and shade: summary and prognostications. Austral. J. Pl. Physiol. 15: 1-9.

PARKER, G.A. \& J.M. SMITH (1990). Optimality theory in evolutionary biology. Nature 348: 27-33.

PEARCY, R.W. (1983). The light environment and growth of $\mathrm{C} 3$ and $\mathrm{C} 4$ tree species in the understory of a Hawaiian forest. Oecologia 58: 19-25.

Pearcy, R.W. (1999). Response of plants to heterogeneous light environments. In: F.I. Pugnaire \& F. Valladares (eds.), Handbook of functional plant ecologv: 269-314. New York.

Pearcy, R.W. \& F. Valladares (1999) Resource acquisition by plants: the role of crown architecture. In: M. Press. J.D. Scholes. Barker, M.G. (eds.), Physiological plant ecology: 45-66. London.

PEARCY, R.W. \& W. YANG (1996). A three-dimensional shoot architecture model for assessment of light capture and carbon gain by understory plants. Oecologia 108: 1-12.

PEARCY, R.W. \& W. YANG (1998). The functional morphology of light capture and carbon gain in the redwood-forest understory plant, Adenocaulon bicolor Hook. Funct. Ecol. 12: 543-552.

Perttunen, J., R. Sievanen, E. NikinmaA. H. Sallinen, H. SAARENMAA \& J. VAKEVA (1996). Lignum: a tree model based on simple structural units. Ann. Bot. 77 : 87-98.

POORTER, H. \& C. REMKES (1990). Leaf area ratio and net assimilation rate of 24 wild species differing in relative growth rate. Oecologia 83: 553-559.

Prusinkiewicz, P. \& A. Lindenmayer (1996). The algorithmic beauty of plants. New York.

Raven, P.H. (1973). The evolution of Mediterranean floras. Ecol. Stud. 7: 213-224.

Room, P., J. HaNaN \& P. Prusinkiewicz (1996). Virtual plants: new perspectives for ecologists, pathologists and agricultural scientists. Trends Pl. Sci. 1: 33-38.

RuBAN, A.V. \& P. HoRTON (1995). Regulation of nonphotochemical quenching of chlorophyll fluorescence in plants. Austral. J. Pl. Physiol. 22: 221-230.

Russel., G., B. Marshall \& P.G. Jarvis (1989). Plant canopies: their growth. form and function. Cambridge.

RYEL, R.J. \& W. BEYSCHL.AG (1995). Benefits associated with steep foliage orientation in two tussock grasses of the American Intermountain West. A look at wateruse-efficiency and photoinhibition. Flora 190: 251260.

Ryel, R.J., W. BeysChlaG \& M.M. CALDWEll (1993). Foliage orientation and carbon gain in two tussock grasses as assessed with a new whole-plant gasexchange model. Funct. Ecol. 7: 115-124.

RYEL, R.J.. W. BEYSCHLAG \& M.M. CALDWELL (1994). Light field heterogeneity among tussock grasses: theoretical considerations of light harvesting and seedling establishment in tussocks and uniform tiller distributions. Oecologia 98: 241-246.

SCHLICHTING, C.D. (1986). The evolution of phenotypic plasticity in plants. Annual. Rev: Ecol. Syst. 17: 667-693. 
SChlichting, C.D. \& M. PigliucCi (1998). Phenotypic evolution A reaction norm perspective. Sunderland.

SiNOQuET, H., P. Rivet \& C. GODIN (1997). Assessment of the three-dimensional architecture of walnut trees using digitising. Silva Fenn. 31: 265-273.

SPECHT, R.L. (1969). A comparison of the sclerophyllous vegetation characteristic of mediterranean type climates in France, California and southern Australia. Austal. J. Bot. 17: 272-292.

TERBORGH, J. (1992). Diversity and the tropical forest. Scientific American Library, New York.

VALLADARES, F. (1999) Architecture, ecology and evolution of plant crowns. In: F.I. Pugnaire \& F. Valladares (eds.), Handbook of functional plant ecology: 121-194. New York.

Valladares, F., E. Martínez-Ferri, L. Balaguer, E. Pérez-Corona \& E. Manrique (2000a). Plastic leaf response to light and nutrients in two Mediterranean evergreen oaks. New Phytol. (in press).

Valladares, F. \& R.W. PEarcy (1997). Low leaf-level response to light and nutrients in mediterranean evergreen oaks: a conservative resource-use strategy? Pl. Cell Environm. 20: 25-36.

Valladares, F. \& R.W. Pearcy (1998). The functional ecology of shoot architecture in sun and shade plants of Heteromeles arbutifolia M. Roem., a Californian chaparral shrub. Oecologia 114: 1-10.

VALladares, F. \& R.W. PEARCY (1999). The geometry of light interception by shoots of Heteromeles arbutifolia: morphological and physiological consequences for individual leaves. Oecologia 121: 171-182.
Valladares, F. \& F.I. Pugnaire (1999). Tradeoffs between irradiance capture and avoidance in semiarid environments simulated with a crown architecture model. Ann. Bot. 83: 459-470.

VAlLadares, F., S.J. Wright, E. LAsSo, K. KItajima \& R.W. PEARCY (2000b). Plastic phenotypic response to light of 16 congeneric shrubs from a Panamanian rainforest. Ecology 81: (7).

VAN DER Werf, A., M. VAN Nuenen, A.J. Visser \& H. LAMBERS (1993). Contribution of physiological and morphological plant traits to a species competitive ability at high and low nitrogen supply - a hypothesis for inherently fast-growing and slowgrowing monocotyledonous species. Oecologia 94: 434-440.

Wallace, L.L. \& E.L. DunN (1980). Comparative photosynthesis of gap phase successional tree species. Oecologia 45: 331-340.

Werner, C., O. Correia \& W. Beyschlag (1999). Two different strategies of Mediterranean macchia plants to avoid photoinhibitory damage by excessive radiation levels during summer drought. Acta Oecol. 20: 15-23.

WERK, K.S. \& J. EHLERINGER (1984). Non-random leaf orientation in Lactuca serriola L. Pl. Cell Environm. 7:81-87. 